\title{
Thalassobacter arenae sp. nov., isolated from sea sand in Korea
}

\author{
Byung-Yong Kim, ${ }^{1}$ Hang-Yeon Weon, ${ }^{2}$ Jung-A Son, ${ }^{2}$ Chang-Muk Lee, ${ }^{1}$ \\ Seung-Beom Hong, ${ }^{1}$ Young-Ah Jeon, ${ }^{1}$ Bon-Sung Koo ${ }^{1}$ \\ and Soon-Wo Kwon ${ }^{1}$
}

Correspondence

Soon-Wo Kwon swkwon@rda.go.kr

\author{
${ }^{1}$ Korean Agricultural Culture Collection (KACC), Microbial Genetics Division, National Institute of \\ Agricultural Biotechnology, Rural Development Administration (RDA), Suwon 441-707, Republic \\ of Korea \\ ${ }^{2}$ Applied Microbiology Division, National Institute of Agricultural Science and Technology, Rural \\ Development Administration (RDA), Suwon 441-707, Republic of Korea
}

\begin{abstract}
A Gram-negative, short rod-shaped bacterium, strain GA2-M15 ${ }^{\top}$, was isolated from a sea-sand sample at Homi Cape, Pohang city, Republic of Korea. 16S rRNA gene sequence analysis demonstrated that this isolate was unique, showing $95.9 \%$ sequence similarity to the type strain of Thalassobacter stenotrophicus and similarities of 94.0-95.2\% to the type strains of species of the genera Octadecabacter (94.4-95.2\%), Jannaschia (94.0-94.4\%) and Thalassobius (94.0-94.7\%). Chemotaxonomic characteristics (diphosphatidylglycerol, phosphatidylglycerol, phosphatidylethanolamine and phosphatidylcholine as the major polar lipids and $\mathrm{C}_{18: 1} \omega 7 \mathrm{c}$ as the predominant fatty acid) and DNA G + C content (56 mol\%) were also similar to those of Thalassobacter stenotrophicus. 16S rRNA gene sequence similarity, physiological properties and some fatty acid components showed that strain GA2-M15 ${ }^{\top}$ could be differentiated from Thalassobacter stenotrophicus. On the basis of these results, strain GA2-M15 ${ }^{\top}$ is considered to represent a novel species of the genus Thalassobacter, for which the name Thalassobacter arenae sp. nov. is proposed. The type strain is GA2-M15 ${ }^{\top}\left(=\operatorname{KACC} 12675^{\top}=\mathrm{DSM} 19593^{\top}\right)$.
\end{abstract}

The genus Thalassobacter was described to accommodate a single bacterial strain isolated from Mediterranean seawater (Macián et al., 2005). A subsequent polyphasic taxonomic approach revealed that the type strains of Jannaschia cystaugens (Adachi et al., 2004) and Thalassobacter stenotrophicus (Macián et al., 2005) were highly similar and should be considered to be members of the same species. Pujalte et al. (2005) thus proposed the unification of the two species as Thalassobacter stenotrophicus and provided an emended description of the genus Thalassobacter. Phylogenetically, this genus is a member of the Alphaproteobacteria, and is closely related to the genera Jannaschia, Octadecabacter and Thalassobius. Thalassobacter was characterized as comprising Gramnegative, strictly aerobic, chemo-organotrophic, slightly halophilic bacteria, with $\mathrm{C}_{18: 1} \omega 7 c$ as the major fatty acid

\section{Abbreviation: Bchl a, bacteriochlorophyll a.}

The GenBank/EMBL/DDBJ accession number for the 16S rRNA gene sequence of strain GA2-M15 ${ }^{\top}$ is EU342372.

A transmission electron micrograph of a cell of strain GA2-M15 $5^{\top}$ and polar lipid profiles of strains GA2-M15 ${ }^{\top}$ and Thalassobacter stenotrophicus DSM $16310^{\top}$ are available as supplementary material with the online version of this paper. and phosphatidylglycerol, diphosphatidylglycerol and phosphatidylcholine as the major polar lipids.

Strain GA2-M15 ${ }^{\mathrm{T}}$ was isolated from a sea-sand sample collected from the coast of Homi Cape, Pohang city, Republic of Korea. Isolation of the strain was performed by using the standard dilution-plating method on marine agar 2216 (MA; Difco) kept at $30{ }^{\circ} \mathrm{C}$ for 10 days. The culture was maintained routinely on $\mathrm{MA}$ at $30{ }^{\circ} \mathrm{C}$ and was preserved as glycerol suspensions $(15 \%, \mathrm{v} / \mathrm{v})$ at $-80{ }^{\circ} \mathrm{C}$. Strain GA2$\mathrm{M} 15^{\mathrm{T}}$ grew weakly on nutrient agar (NA), but did not grow on R2A, trypticase soy agar (TSA) or MacConkey agar (all from Difco). Thalassobacter stenotrophicus DSM $16310^{\mathrm{T}}$ was obtained from the Deutsche Sammlung von Mikroorganismen und Zellkulturen (DSMZ), Braunschweig, Germany, and was used as a reference strain.

The methods described by Smibert \& Krieg (1994) were used for Gram staining and to detect accumulation of polyhydroxybutyrate, the presence of catalase and oxidase, and hydrolysis of casein, DNA and starch. Hydrolysis of alginic acid $(0.5 \%, \mathrm{w} / \mathrm{v}), \mathrm{CM}$-cellulose $(0.1 \%$, w/v), chitin from crab shells $(1 \%$, w/v), pectin $(0.5 \%$, w/v) and tyrosine $(0.5 \%, \mathrm{w} / \mathrm{v})$ was checked on MA after 14 days incubation. Cell morphology was studied by transmission 
electron microscopy (model 912AB; LEO) and phasecontrast microscopy (AXIO; Zeiss), with cells grown for 3 days at $30{ }^{\circ} \mathrm{C}$ on MA. The temperature range for growth was tested on MA from 5 to $45{ }^{\circ} \mathrm{C}$ at increments of $5{ }^{\circ} \mathrm{C}$. The $\mathrm{pH}$ range for growth was determined in the range $\mathrm{pH} 5-10$ at increments of $1 \mathrm{pH}$ unit by using marine broth buffered with citrate/phosphate buffer or Tris/ $\mathrm{HCl}$ buffer (Breznak \& Costilow, 1994). The salinity range for growth was tested on MA. The minimal amount of salts required for growth was determined on diluted MA containing 0.34 , $0.68,0.85,1.02,1.36,1.7,2.04,2.55$ and $3.06 \%(\mathrm{w} / \mathrm{v})$ total salts (dilution factors of $0.1,0.2,0.25,0.3,0.4,0.5,0.6,0.75$ and 0.9 , respectively). The loss of nutrients and agar by dilution was compensated for by adding the appropriate amounts of peptone, yeast extract and agar. The highest salinity that supported growth was determined on MA plus $\mathrm{NaCl}$ up to $6,7,8,9$ and $10 \%(\mathrm{w} / \mathrm{v})$ total salinity [2.6, 3.6, 4.6, 5.6 and $6.6 \%(\mathrm{w} / \mathrm{v}) \mathrm{NaCl}$, respectively]. To determine ionic requirements for growth, salt-tolerance agar [STA: $1 \%(\mathrm{w} / \mathrm{v})$ tryptone, $0.3 \%(\mathrm{w} / \mathrm{v})$ yeast extract and $1.5 \%$ $(w / v)$ agar] was supplemented with the following combinations of salts: (i) $2 \%(\mathrm{w} / \mathrm{v}) \mathrm{NaCl}$; (ii) $2 \%(\mathrm{w} / \mathrm{v}) \mathrm{NaCl}$, $0.9 \%(\mathrm{w} / \mathrm{v}) \mathrm{MgCl}_{2} \cdot 6 \mathrm{H}_{2} \mathrm{O}, 0.2 \%$ (w/v) $\mathrm{CaCl}_{2} \cdot 2 \mathrm{H}_{2} \mathrm{O}$ and $0.06 \%(\mathrm{w} / \mathrm{v}) \mathrm{KCl}$ (all concentrations equal to those found in $\mathrm{MB}$ for these four salts); and (iii) $2 \%(\mathrm{w} / \mathrm{v}) \mathrm{NaCl}, 0.9 \%$ (w/v) $\mathrm{MgSO}_{4} \cdot 7 \mathrm{H}_{2} \mathrm{O}, 0.2 \%$ (w/v) $\mathrm{CaCl}_{2} \cdot 2 \mathrm{H}_{2} \mathrm{O}$ and $0.06 \%$ (w/v) KCl. Anaerobic growth was tested on MA incubated in an anaerobic jar (BBL). Carbon utilization was tested on basal medium agar [BMA: $50 \mathrm{mM}$, Tris/ $\mathrm{HCl}, \mathrm{pH}$ 7.5; $190 \mathrm{mM}, \quad \mathrm{NH}_{4} \mathrm{Cl} ; 0.33 \mathrm{mM} \quad \mathrm{K}_{2} \mathrm{HPO}_{4} \cdot 3 \mathrm{H}_{2} \mathrm{O} ; 0.1 \mathrm{mM}$ $\mathrm{FeSO}_{4} \cdot \mathrm{H}_{2} \mathrm{O}$; and $1.5 \%$ Bacto agar (Difco) in half-strength artificial seawater; Baumann \& Baumann, 1981] containing $0.2 \%$ carbon source. BMA was supplemented with $0.01 \%$ yeast extract. Tests in the API 20NE and API ZYM (bioMérieux) commercial systems were performed according to the manufacturer's instructions.

Cells of strain GA2-M15 ${ }^{\mathrm{T}}$ were Gram-negative, short rods with polar flagella (see Supplementary Fig. S1 in IJSEM Online). In the minimal salinity test for growth, restriction of growth was observed from $0.85 \% \mathrm{NaCl}(\mathrm{w} / \mathrm{v})$, and no growth was observed in the presence of $0.34 \% \mathrm{NaCl}(\mathrm{w} / \mathrm{v})$. In the maximum salinity test for growth, restriction of growth was observed from $8 \%(\mathrm{w} / \mathrm{v})$ total salinity, and no growth was observed above $10 \%(\mathrm{w} / \mathrm{v})$ total salinity. In tests of ionic requirements for growth, strain GA2-M15 ${ }^{\mathrm{T}}$ showed good growth on STA with four added salts [media (ii) and (iii)] whereas it was not able to grow on STA or on STA plus $2 \% \mathrm{NaCl}$ [medium (i)]. Assimilation of substrates within the API 20NE system was not observed, indicating that the minimal medium as used here was not appropriate for tests of growth. A comparison of the phenotypic properties of strain GA2-M15 ${ }^{\mathrm{T}}$ and Thalassobacter stenotrophicus DSM $16310^{\mathrm{T}}$ is given in Table 1. Strain GA2$\mathrm{M}^{2} 5^{\mathrm{T}}$ was more versatile as regards substrate utilization and enzyme activities than Thalassobacter stenotrophicus.

For the measurement of bacteriochlorophyll $a(\operatorname{Bchl} a)$, cells were grown in the dark on MA and MB medium.
Table 1. Differential phenotypic characteristics between strain GA2-M15 ${ }^{\top}$ and Thalassobacter stenotrophicus DSM $16310^{\top}$

The two strains are strictly aerobic, motile and positive for polyhydroxybutyrate accumulation, catalase and oxidase. They assimilate D-glucose, L-glutamate, $\beta$-hydroxybutyrate, D-mannitol, pyruvate and L-serine, but not L-alanine, L-arabinose, L-aspartate, cellobiose, glycine, L-histidine, lactose, L-leucine, maltose, L-rhamnose, D-ribose, sucrose, L-threonine or trehalose. The two strains are positive for aesculin hydrolysis, but negative for nitrate reduction, indole production, glucose fermentation, arginine dihydrolase and gelatin hydrolysis (API 20NE test strips). +, Positive; -, negative or not detected (or comprising $<1 \%$ of the total fatty acids).

\begin{tabular}{|c|c|c|}
\hline Characteristic & GA2-M15 ${ }^{\mathrm{T}}$ & $\begin{array}{l}\text { Thalassobacter steno- } \\
\text { trophicus DSM } 16310^{\mathrm{T}}\end{array}$ \\
\hline DNA G $+\mathrm{C}$ content $(\mathrm{mol} \%)$ & 56 & $59^{*}$ \\
\hline$\beta$-Galactosidase & + & - \\
\hline \multicolumn{3}{|l|}{ Assimilation of: } \\
\hline Citrate & + & - \\
\hline D-Fructose & + & $-\dagger$ \\
\hline D-Galactose & + & - \\
\hline Glycerol & + & $-\dagger$ \\
\hline D-Mannose & + & - \\
\hline Melibiose & + & - \\
\hline Propionate & + & - \\
\hline \multicolumn{3}{|l|}{ Enzyme activities (API } \\
\hline \multicolumn{3}{|l|}{$\mathrm{ZYM})$} \\
\hline Alkaline phosphatase & - & + \\
\hline Esterase lipase (C8) & + & - \\
\hline$\alpha$-Glucosidase & + & - \\
\hline$\beta$-Glucosidase & + & - \\
\hline \multicolumn{3}{|l|}{ Fatty acids (\%) } \\
\hline $\mathrm{C}_{10: 0} 3-\mathrm{OH}$ & 3.7 & 5.4 \\
\hline $\mathrm{C}_{16: 0}$ & 10.4 & 1.1 \\
\hline $\mathrm{C}_{18: 0}$ & 1.2 & 4.5 \\
\hline $\mathrm{C}_{18: 1} \omega 7 c$ & 74.3 & 70.6 \\
\hline $\mathrm{C}_{18: 1} \omega 7 c$ 11-methyl & 5.9 & 6.7 \\
\hline $\mathrm{C}_{18: 1} \omega 9 c$ & - & 2.7 \\
\hline Summed feature $7 \ddagger$ & - & 2.5 \\
\hline Unknown 11.799 & 3.0 & 4.5 \\
\hline
\end{tabular}

${ }^{\star}$ Data from Macián et al. (2005).

$\dagger$ Reported as positive by Pujalte et al. (2005).

$\ddagger$ Summed feature 7 comprises unknown 18.846 and/or $C_{19: 1} \omega 6$ c.

Extraction of Bchl $a$ was attempted with acetone (Takaichi et al., 1991), acetone/methanol (1:1, v/v) (Lafay et al., $1995)$ and acetone/methanol $(7: 2, \mathrm{v} / \mathrm{v})$ (Hiraishi et al., 1998). However, cells were not disrupted in any of these solvents, and extraction of Bchl $a$ was not possible.

Analyses of whole-cell fatty acid patterns followed the methods given for the MIDI system (Microbial ID) (Kroppenstedt, 1985; Sasser, 1990) after cells were grown on MA medium for 4 days at $30^{\circ} \mathrm{C}$. Polar lipids were analysed according to Minnikin et al. (1984). The DNA $\mathrm{G}+\mathrm{C}$ content was determined by using HPLC (Mesbah 
et al., 1989). The predominant cellular fatty acid of strain GA2-M15 ${ }^{\mathrm{T}}$ was $\mathrm{C}_{18: 1} \omega 7 c(74.3 \%)$, followed by $\mathrm{C}_{16: 0}$ $(10.4 \%)$ and lesser amounts of $\mathrm{C}_{18: 1} \omega 7 c$ 11-methyl (5.9\%), $\quad \mathrm{C}_{10: 0} \quad 3-\mathrm{OH} \quad(3.7 \%)$ and unknown 11.799 $(3.0 \%)$. Strain GA2-M $15^{\mathrm{T}}$ contained a greater proportion of $\mathrm{C}_{16: 0}$ than Thalassobacter stenotrophicus DSM $16310^{\mathrm{T}}$ (10.4 and $1.1 \%$, respectively). The polar lipid profiles of the two strains (Supplementary Fig. S2) were similar, containing diphosphatidylglycerol, phosphatidylglycerol, phosphatidylethanolamine and phosphatidylcholine. The presence of phosphatidylethanolamine in Thalassobacter stenotrophicus DSM $16310^{\mathrm{T}}$ in the present study was in contrast to the results of Pujalte et al. (2005). The DNA $\mathrm{G}+\mathrm{C}$ content of strain $\mathrm{GA} 2-\mathrm{M} 15^{\mathrm{T}}$ was $56 \mathrm{~mol} \%$, compared with $59 \mathrm{~mol} \%$ for Thalassobacter stenotrophicus DSM $16310^{\mathrm{T}}$.

Genomic DNA was extracted by using a DNeasy Tissue kit (Qiagen) following the manufacturer's instructions. Sequencing of the 16S rRNA gene was performed as described by Kwon et al. (2003). The $16 \mathrm{~S}$ rRNA gene sequence of strain GA2-M $15^{\mathrm{T}}$ determined in this study was a continuous stretch of $1396 \mathrm{bp}$. Multiple alignments were performed by using the program CLUSTAL $\mathrm{w}$ (Thompson et al., 1994). Evolutionary distances were calculated by using Kimura's two-parameter model (Kimura, 1983). Phylogenetic trees were constructed according to the neighbour-joining (Saitou \& Nei, 1987) and maximumparsimony (Fitch, 1971) methods by using the program MEGA3 (Kumar et al., 2004), with bootstrap values based on 1000 replications (Felsenstein, 1985). Based on 16S rRNA gene sequences, strain GA2-M15 ${ }^{\mathrm{T}}$ was related most closely to the type strain of Thalassobacter stenotrophicus (95.9\% similarity). Members of the genera Octadecabacter (94.4$95.2 \% 16 \mathrm{~S}$ rRNA gene sequence similarity), Jannaschia
(94.0-94.4\%) and Thalassobius (94.0-94.7\%) were also revealed as close phylogenetic neighbours of strain GA2$\mathrm{M}^{\mathrm{T}}{ }^{\mathrm{T}}$. According to the neighbour-joining tree (Fig. 1), strain GA2-M $15^{\mathrm{T}}$ clustered with Thalassobacter stenotrophicus CECT $5294^{\mathrm{T}}$, albeit with a rather low bootstrap value $(30 \%)$.

On the basis of the results presented here, strain GA2$\mathrm{M} 15^{\mathrm{T}}$ is considered to represent a novel species of the genus Thalassobacter, for which the name Thalassobacter arenae sp. nov. is proposed.

\section{Description of Thalassobacter arenae sp. nov.}

Thalassobacter arenae (a.re' nae. L. gen. n. arenae of sand).

Cells are strictly aerobic, Gram-negative, short rods (0.7$1.2 \mu \mathrm{m}$ wide and $1.2-2.4 \mu \mathrm{m}$ long). Motile by means of polar flagella. Accumulates polyhydroxybutyrate. Catalaseand oxidase-positive. Does not reduce nitrate or ferment glucose. Colonies are deep-brown, circular and with clear margins. Grows at $5-35{ }^{\circ} \mathrm{C}$ (optimum $30{ }^{\circ} \mathrm{C}$ ) and at $\mathrm{pH} 6-$ 9 (optimum $\mathrm{pH} 7$ ). Grows in the presence of $0.85-8 \%$ $\mathrm{NaCl}(\mathrm{w} / \mathrm{v})$, but not at or below $0.34 \%$ or at or above $10 \%$ $\mathrm{NaCl}(\mathrm{w} / \mathrm{v})$. Hydrolyses aesculin and hydrolyses tyrosine weakly, but does not hydrolyse alginic acid, casein, chitin, CM-cellulose, DNA, gelatin, pectin, starch or urea. Assimilates citrate, D-fructose, D-galactose, D-glucose, L-glutamate, glycerol, $\beta$-hydroxybutyrate, D-mannitol, D-mannose, melibiose, propionate, pyruvate, L-serine, L-tyrosine and D-xylose, but not L-alanine, L-arabinose, L-aspartate, cellobiose, glycine, L-histidine, lactose, Lleucine, maltose, L-rhamnose, D-ribose, sucrose, L-threonine or trehalose. Positive for $\beta$-galactosidase, esterase (C4), esterase lipase (C8), leucine arylamidase, naphtholAS-BI-phosphohydrolase, $\alpha$-glucosidase and $\beta$-glucosidase,



Fig. 1. Neighbour-joining phylogenetic tree constructed based on a comparative analysis of $16 \mathrm{~S}$ rRNA gene sequences showing the relationships between strain GA2-M15 ${ }^{\top}$ and related species. Bootstrap values (expressed as percentages of 1000 replications) of $>50 \%$ are shown at branch points. Circles indicate branches replicated in the maximum-parsimony tree. Bar, 0.01 substitutions per site. 
but negative for indole production, arginine dihydrolase, alkaline phosphatase, lipase (C14), valine arylamidase, cystine arylamidase, trypsin, $\alpha$-chymotrypsin, acid phosphatase, $\alpha$-galactosidase, $\beta$-glucuronidase, $N$-acetyl- $\beta$-glucosaminidase, $\alpha$-mannosidase and $\alpha$-fucosidase (API $20 \mathrm{NE}$ and API ZYM test strips). The major fatty acids are $\mathrm{C}_{18: 1} \omega 7 c$ and $\mathrm{C}_{16: 0}$. The predominant polar lipids are diphosphatidylglycerol, phosphatidylglycerol, phosphatidylethanolamine and phosphatidylcholine. The $\mathrm{G}+\mathrm{C}$ content of the DNA of the type strain is $56.0 \mathrm{~mol} \%$.

The type strain, GA2-M $15^{\mathrm{T}}$ (=KACC $12675^{\mathrm{T}}=\mathrm{DSM}$ $19593^{\mathrm{T}}$ ), was isolated from a sea-sand sample from Homi Cape, Pohang city, Republic of Korea.

\section{Acknowledgements}

This work was supported by a grant (no. 06-4-11-19-1) from the National Institute of Agricultural Biotechnology, Rural Development Administration, Republic of Korea.

\section{References}

Adachi, M., Kanno, T., Okamoto, R., Shinozaki, A., Fujikawa-Adachi, K. \& Nishijima, T. (2004). Jannaschia cystaugens sp. nov., an Alexandrium (Dinophyceae) cyst formation-promoting bacterium from Hiroshima Bay, Japan. Int J Syst Evol Microbiol 54, 1687-1692.

Baumann, P. \& Baumann, L. (1981). The marine Gram-negative eubacteria: genera Photobacterium, Beneckea, Alteromonas, Pseudomonas, and Alcaligenes. In The Prokaryotes, pp. 1302-1330. Edited by M. P. Starr, H. Stolp, H. G. Trüper, A. Balows \& H. G. Schlegel. Berlin: Springer.

Breznak, J. A. \& Costilow, R. N. (1994). Physicochemical factors in growth. In Methods for General and Molecular Bacteriology, pp. 137154. Edited by P. Gerhardt, R. G. E. Murray, W. A. Wood \& N. R. Krieg. Washington, DC: American Society for Microbiology.

Felsenstein, J. (1985). Confidence limits on phylogenies: an approach using the bootstrap. Evolution 39, 783-791.

Fitch, W. M. (1971). Toward defining the course of evolution: minimum change for a specific tree topology. Syst Zool 20, 406-416.

Hiraishi, A., Nagashima, K. V. P., Matsuura, K., Shimada, K., Takaichi, S., Wakao, N. \& Katayama, Y. (1998). Phylogeny and photosynthetic features of Thiobacillus acidophilus and related acidophilic bacteria: its transfer to the genus Acidiphilium as Acidiphilium acidophilum comb. nov. Int J Syst Bacteriol 48, 1389-1398.

Kimura, M. (1983). The Neutral Theory of Molecular Evolution. Cambridge: Cambridge University Press.
Kroppenstedt, R. M. (1985). Fatty acid and menaquinone analysis of actinomycetes and related organisms. In Chemical Methods in Bacterial Systematics (SAB Technical Series no. 20), pp. 173-199. Edited by M. Goodfellow \& D. E. Minnikin. London: Academic Press.

Kumar, S., Tamura, K. \& Nei, M. (2004). MEGA3: integrated software for molecular evolutionary genetics analysis and sequence alignment. Brief Bioinform 5, 150-163.

Kwon, S. W., Kim, J. S., Park, I. C., Yoon, S. H., Park, D. H., Lim, C. K. \& Go, S. J. (2003). Pseudomonas koreensis sp. nov., Pseudomonas umsongensis sp. nov. and Pseudomonas jinjuensis sp. nov., novel species from farm soils in Korea. Int J Syst Evol Microbiol 53, 21-27.

Lafay, B., Ruimy, R., Rausch de Traubenberg, C., Breittmayer, V., Gauthier, M. J. \& Christen, R. (1995). Roseobacter algicola sp. nov., a new marine bacterium isolated from the phycosphere of the toxinproducing dinoflagellate Prorocentrum lima. Int J Syst Bacteriol 45, 290-296.

Macián, M. C., Arahal, D. R., Garay, E., Ludwig, W., Schleifer, K. H. \& Pujalte, M. J. (2005). Thalassobacter stenotrophicus gen. nov., sp. nov., a novel marine $\alpha$-proteobacterium isolated from Mediterranean sea water. Int J Syst Evol Microbiol 55, 105-110.

Mesbah, M., Premachandran, U. \& Whitman, W. B. (1989). Precise measurement of the $\mathrm{G}+\mathrm{C}$ content of deoxyribonucleic acid by highperformance liquid chromatography. Int J Syst Bacteriol 39, 159-167.

Minnikin, D. E., O'Donnell, A. G., Goodfellow, M., Alderson, G., Athalye, M., Schaal, A. \& Parlett, J. H. (1984). An integrated procedure for the extraction of bacterial isoprenoid quinones and polar lipids. J Microbiol Methods 2, 233-241.

Pujalte, M. J., Macián, M. C., Arahal, D. R. \& Garay, E. (2005). Thalassobacter stenotrophicus Macián et al. 2005 is a later synonym of Jannaschia cystaugens Adachi et al. 2004, with emended description of the genus Thalassobacter. Int J Syst Evol Microbiol 55, 1959-1963.

Saitou, N. \& Nei, M. (1987). The neighbor-joining method: a new method for reconstructing phylogenetic trees. Mol Biol Evol 4, 406425.

Sasser, M. (1990). Identification of bacteria by gas chromatography of cellular fatty acids, MIDI Technical Note 101. Newark, DE: MIDI Inc.

Smibert, R. M. \& Krieg, N. R. (1994). Phenotypic characterization. In Methods for General and Molecular Bacteriology, pp. 607-654. Edited by P. Gerhardt, R. G. E. Murray, W. A. Wood \& N. R. Krieg. Washington, DC: American Society for Microbiology.

Takaichi, S., Furihata, K., Ishidu, J. \& Shimada, K. (1991). Carotenoid sulphates from the aerobic photosynthetic bacterium, Erythrobacter longus. Phytochemistry 30, 3411-3415.

Thompson, J. D., Higgins, D. G. \& Gibson, T. J. (1994). CLUSTAL W: improving the sensitivity of progressive multiple sequence alignment through sequence weighting, position-specific gap penalties and weight matrix choice. Nucleic Acids Res 22, 4673-4680. 